\author{
INSTITUT AGAMA ISLAM IMAM GHOZALI (IAIIG) CILACAP \\ LPPM (Lembaga Penelitian dan Pengabdian Masyarakat) \\ Al-Munqidz: Jurnal Kajian Keislaman \\ Jl. Kemerdekaan Barat No.17 Kesugihan-Cilacap || https://ejournal.iaiig.ac.id/index.php/amk \\ Issn SK no. : 0005.235/JI.3.2/SK.ISSN/2012.07 || 0005.27158462/JI.3.1/SK.ISSN/2020.01
}

\title{
PROBLEMATIKA GENDER DALAM ISLAM (Telaah Pendekatan Kontekstual)
}

\author{
Ahmad Sahal Mubarok ${ }^{1}$, Saekhoni ${ }^{2}$, Ahmad Sirfi Fatoni ${ }^{3}$ \\ UIN Sunan Kalijaga Yogyakarta ${ }^{1,3}$, IAIIG Cilacap ${ }^{2}$ \\ E-mail: $\underline{\text { kangsahal30@gmail.com }}{ }^{1}, \underline{\text { saekhoni64@gmail.com }}{ }^{2}, \underline{\text { ahmadsirfi20@ gmail.com }^{3}}$
}

Naskah Diterima

27 Agustus 2020

Publis Artikel

7 September 2020
Abstract: This article examines about gender problem by using a contextual approach. This approach means understanding Islam in accordance with the current situation, in this corridor of course the situation will always change, the situation past, present and future will definitely experience differences. Need to know carefully, until now gender issues still has a serious impact on the global arena. Why is that, because this issue is often clashed with religion dogmas, especially Islam religion which is the tendency to not generalize in its laws has subordinate the woman's party. It appears in the matter of legacy and testimony distribution. This type of research is a qualitative research which has a descriptive analysis characteristic. As for the research results among others: 1) By using the contextual approach, talking about the relationship between men and women in islam in principle can be considered the same as talking around the parallel between the both of them. Because in the religion of Islam in principle the relationship between the both of sexes is equal before Allah as is evident in the surah Al-Hujura@t verse 13. In addition, the great mission of Islam is rahmatan li al-alamin; 2) The government policies including in the world of work, should pay serious attention to equal opportunities for both men and women in the supply of available employment opportunities regardless of gender construction, so that it will produce a justice without inequality. For example, a green revolution program designed without considering gender aspects, in which to harvest the rice is used by a sickle cutting system, not by ani-ani, even though that tool is attached to the women; 3) The Koran as a reference to the principle of society recognizes that the position of men and women is equal. The both of them are created from one nafs, which is the one has no advantage over the other. Even the Koran doesn't explicitly explain that 
Hawa was created from Adam's rib so that her status was lower. On that basis, the principle of the Koran for men and women is the same, where the right of the wife is recognized as equal to the right of the husband, including inheritance and testimony. The action that must be needed now is to bulid a proportional synthesis between the Koran, classical Islamic literature and modern science in order to reinterpret gender issue in depth which is the majority of his understanding is marginalize the women.

Keywords: Gender, Contextual Approach, Religious Interpretation, Government Policy, Modern Science.

Abstrak: Artikel ini mengkaji tentang problematika gender dengan memakai pendekatan kontekstual. Pendekatan ini berarti memahami islam sesuai dengan situasi yang sedang terjadi, dalam koridor ini tentu saja situasi akan selalu berubah, situasi dulu, sekarang dan mendatang pasti mengalami diverification. Perlu diketahui secara seksama bahwa isu gender sampai sekarang masih menimbulkan dampak yang pelik di kancah global. Mengapa demikian, karena isu ini kerap kali dibenturkan dengan dogma-dogma agama, khususnya agama islam yang kecenderungannya dengan tidak menggeneralisir dalam hukum-hukumnya telah mensubordinasikan pihak perempuan. Hal itu nampak dalam masalah pembagian warisan dan kesaksian. Jenis penelitian ini adalah penelitian kualitatif yang memiliki sifat deskriptif analisis. Adapun hasil penelitiannya diantaranya: 1) Dengan menggunakan pendekatan kontekstual, berbicara hubungan laki-laki dengan perempuan dalam islam pada prinsipnya dapat dianggap sama artinya dengan berbicara sekitar kemitrasejajaran antara keduanya. Sebab dalam islam secara prinsip hubungan kedua jenis kelamin ini adalah sejajar di hadapan Allah sebagaimana nampak jelas dalam surat AlHujura@t ayat 13. Di samping itu, misi besar agama islam adalah rahmatan li al-alamin; 2) Kebijakan pemerintah termasuk dalam dunia kerja, hendaknya memperhatikan secara serius tentang kesempatan yang sama bagi laki-laki maupun perempuan dalam persediaan peluang kerja yang ada tanpa membedakan kontruksi gender, sehingga akan menghasilkan sebuah keadilan tanpa ketimpangan. Misalnya, program revolusi hijau yang dirancang tanpa mempertimbangkan aspek gender, yang mana untuk memanen padi digunakan sistem tebang dengan sabit, tidak lagi dengan ani-ani, padahal alat tersebut melekat pada perempuan.; 3) Al-Qur'an sebagai rujukan prinsip masyarakat mengakui 
bahwa kedudukan laki-laki dan perempuan ialah sama. Keduanya diciptakan dari satu nafs, di mana yang satu tidak memiliki keunggulan terhadap yang lain. Bahkan al-Qur'an tidak menjelaskan secara tegas bahwa Hawa diciptakan dari tulang rusuk Adam sehingga statusnya lebih rendah. Atas dasar itu, prinsip al-Qur'an terhadap kaum laki-laki dan perempuan adalah sama, di mana hak istri diakui sederajat dengan hak suami, termasuk dalam warisan dan kesaksian. Tindakan yang harus diperlukan sekarang ialah membangun sintesa secara proporsional antara Kitab Suci, literatur islam klasik dan sains modern guna mereinterpretasi ulang masalah gender secara mendalam yang mana mayoritas pemahamannya menyudutkan kaum perempuan.

Kata Kunci: Gender, Pendekatan Kontekstual, Tafsir Keagamaan, Kebijakan Pemerintah, Sains Modern.

\section{A. Pendahuluan}

Pada saat ini umat islam sedang menghadapi tantangan dari kehidupan dunia dan budaya modern, studi islam menjadi sangat urgen. Studi islam dituntut untuk membuka diri terhadap masuknya dan digunakannya pendekatan-pendekatan yang bersifat obyektif dan rasional. Dengan demikian diharapkan studi islam akan berkembang dan mampu beradaptasi dengan dunia modern serta mampu menjawab tantangan kehidupan dunia dan budaya modern. Urgensi studi islam yang demikian dapat dipahami dan diuraikan dengan salah satu pendekatan dalam studi islam yaitu pendekatan kontekstual (Muhaimin, 2012: 3).

Dalam kamus al-Maurid (Inggris-Arab), context diartikan dengan: (1) al- qarinah (indikasi) atau siyaq al-kalam (kaitan-kaitan, latar belakang "duduk perkara" suatu pernyataan), (2) bi"ah (suasana) atau muhit (yang meliputi). Kontekstual diartikan dengan mutawaqqif ,, ala al-qarinah (mempertimbangkan indikasi) (Syafrudin, 2017: 43). Dengan demikian dapat diambil definisi bahwa pendekatan kontekstual atau tafsir kontekstual yaitu pendekatan tafsir yang secara paradigmatik atau orientasinya berkecenderungan pada penafsiran al-qur'an yang tidak semata-mata berpegang teguh pada makna lahiriah teks (literal), tetapi juga menekankan dimensi konteks yang menyertai teks, dalam konteks realitas apa suatu teks hendak ditafsirkan, dan terutama mengedepankan nilai-nilai substantif teks yang bermuara pada kepentingan maslahat manusia dalam situasi dan kondisi yang berubah. Karena itu, maka diperlukan konteks yang menyertai penafsir (Syafrudin, 2017: 52). Dalam pengertian, bahwa ayat-ayat Al-qur'an harus didialogkan dengan realitas kekinian sehingga dapat menampilkan solusi terhadap 


\section{Ahmad Sahal Mubarok ${ }^{1}$, Saekhoni², Ahmad Sirfi Fatoni"; "PROBLEMATIKA GENDER DALAM ISLAM (Telaah Pendekatan Kontekstual)"}

berbagai problematika kemanusiaan yang semakin kompleks dan pelik, khususnya dalam makalah ini penulis mengangkat isu gender.

Memerangi ketidakadilan sosial sepanjang sejarah kemanusiaan selalu menjadi tema krusial dan penting dalam setiap pemikiran dan konsepsi tentang kemasyarakatan di masa mendatang, termasuk dalam hal ini yaitu isu gender. Isu ini dianggap menarik dan selalu terjadi perdebatan sepanjang masa. Banyak pemikir kontemporer yang pro maupun kontra tentang isu gender ini. Mereka mengajukan argumennya masing-masing sesuai kerangka konseptual yang mereka bangun dan geluti melalui beberapa pendekatan. Isu ini sangat kompatibel untuk dikaji melalui pendekatan kontekstual, dikarenakan secara hermeneutis, pendekatan ini bersifat produktif yaitu lebih mengedepankan aspek inklusif- pluralis dalam setiap aktivitas penafsirannya. Ini terjadi karena orientasi yang hendak dituju lebih diarahkan pada bagaimana islam dan seperangkat nilai yang dikandungnya membawa kemaslahatan dan rahmatan lil 'alamin pada seluruh umat. Dalam masalah gender, apakah al-qur'an mengajarkan keadilan gender atau ketidakadilan gender melalui pendekatan kontekstual, itulah salah satu hal yang perlu dipenakan serta menjadi sorotan dalam penelitian ini. Apakah teks al-qur'an yang sudah absah dan telah ditafsirkan oleh beberapa ulama klasik sampai modern sudah dapat memecahkan isu gender? Dan apakah pesan moral ideal al-qur'an tentang isu gender sudah dipahami dan diterima oleh kaum laki-laki maupun perempuan?

\section{B. Pembahasan}

Untuk memahami apa yang dimaksud dengan gender perlu pula dijelaskan tentang pengertian sex. Dengan pemahaman ini diharapkan pada gilirannya dipahami pula apa perbedaannya dengan sex. Kemudian setelah itu dapat dikemukakan bagaimana konsep islam melalui pendekatan kontekstual tentang kasus gender. Kata gender berasal dari bahasa Inggris gender yang berarti jenis kelamin. Menurut Nasaruddin Umar, pengertian ini kurang tepat, sebab dengan pengertian tersebut gender disamakan dengan sex yang berarti jenis kelamin pula. Persoalan ini muncul barangkali adalah karena kata gender termasuk kosakata baru, sehingga pengertiannya belum ditemukan dalam Kamus Besar Bahasa Indonesia.

Dalam Webster"s New World Dictionary, gender diartikan sebagai perbedaan yang tampak antara laki-laki dan perempuan dari segi nilai dan tingkah laku. Dalam Women"s Studies Encyclopedia dijelaskan bahwa gender adalah konsep yang bersifat budaya (cultural) 

DALAM ISLAM (Telaah Pendekatan Kontekstual)"

yang berupaya membuat perbedaan dalam hal peran, perilaku, mentalitas dan karakteristik emosional antara laki-laki dan perempuan yang berkembang dalam masyarakat. Meskipun kata gender belum masuk dalam perbendaharaan Kamus Besar Bahasa Indonesia, istilah tersebut sudah lazim dipergunakan, khususnya di Kantor Menteri Urusan Peranan Wanita dengan ejaan "gender". Gender diartikan sebagai penafsiran yang bersifat mental (interpretasi mental) dan budaya terhadap perbedaan kelamin, laki-laki dan perempuan. Gender biasanya dipergunakan untuk menunjukkan pembagian kerja yang tepat bagi laki-laki dan perempuan (Khoiruddin, 2012: 228-229).

Mansour Fakih menguraikan pengertian gender secara lebih mendetail beserta contohcontohnya. Menurutnya, gender adalah sifat yang melekat pada laki-laki dan perempuan yang dikonstruksi secara sosial maupun kultural. Misalnya, perempuan dikenal lemah lembut, cantik, emosional dan keibuan. Sedangkan laki- laki dianggap kuat, rasional, jantan dan perkasa. Ciri-ciri dan sifat-sifat tersebut merupakan sifat-sifat yang dapat dipertukarkan. Artinya ada laki-laki yang emosional, lemah lembut, keibuan, sementara ada juga perempuan yang rasional. kuat dan perkasa. Perubahan ciri dari sifat-sifat tersebut dapat terjadi dari waktu ke waktu dan dari tempat ke tempat lain. Jadi yang disebut gender adalah semua hal yang dapat dipertukarkan antara sifat perempuan dan laki-laki yang bisa berubah dari waktu ke waktu serta dapat berbeda dari satu tempat ke tempat lainnya maupun berbeda dari satu kelas ke kelas lain.

Untuk membedakan antara gender dan sex, perlu pula diberikan pengertian sex. Kata "sex" dalam bahasa Indonesia diartikan "jenis kelamin". Kalau ada kata sex, maka diisi dengan laki-laki dan perempuan. Namun perbedaan kedua jenis kelamin manusia ini, ditentukan secara biologis. Maksud perbedaan berdasarkan biologis adalah perbedaan yang didasarkan pada hal yang bersifat permanen (kudrati), tidak dapat dipertukarkan. Misalnya, laki-laki mempunyai penis, sementara perempuan mempunyai vagina. Perempuan mempunyai payudara yang dapat memproduksi makanan untuk anak, sementara laki-laki tidak. Pendeknya, perbedaan di sini lebih bersifat paten, kudrat dan tidak dapat dipertukarkan, tidak dapat berubah-ubah dari waktu ke waktu, tidak dapat berubah-ubah dari satu tempat ke tempat lain, tidak dapat dipertukarkan antara satu kelas ke kelas lain. meskipun dapat dipertukarkan dengan menggunakan teknologi, tetapi tetap ada perbedaan hormon-hormon yang ada di dalamnya (Khoiruddin, 2012: 229-231). 

DALAM ISLAM (Telaah Pendekatan Kontekstual)"

Berdasarkan definisi-definisi di atas, dapat disimpulkan bahwa gender adalah konsep perbedaan laki-laki dan perempuan sebagai hasil bentukan sosial budaya, bukan bersifat biologis atau kudrati. Dengan demikian, perbedaannya adalah bersifat non-biologis. Dengan demikian, perbedaan berdasarkan gender dapat dipertukarkan antara laki-laki dan perempuan, dapat dipertukarkan dari satu tempat ke tempat lain, dapat dipertukarkan dari satu kelas ke kelas lain. Berbicara tentang gender, sama artinya dengan berbicara sekitar hubungan wanita dan pria. Berbicara hubungan wanita dan pria dalam islam pada prinsipnya dapat disebut sama artinya dengan berbicara sekitar kemitrasejajaran pria dan wanita. Sebab dalam islam secara prinsip hubungan kedua jenis kelamin ini adalah sejajar di hadapan Allah (khaliq) (Khoiruddin, 2012: 231).

\section{Gender dalam Bingkai Pendekatan Kontekstual}

Sejarah perbedaan gender antara manusia jenis laki-laki dan perempuan terjadi melalui proses yang panjang. Oleh karena itu terbentuknya perbedaan- perbedaan gender dikarenakan oleh banyak hal, diantaranya dibentuk, disosialisasikan, diperkuat, bahkan dikonstruksi secara sosial atau kultural melalui ajaran keagamaan maupun negara. Melalui proses panjang, sosialisasi gender tersebut akhirnya dianggap menjadi ketentuan Tuhan, seolah-olah bersifat biologis yang tidak dapat dirubah lagi, sehingga perbedaan-perbedaan gender dianggap dan dipahami sebagai kodrat laki-laki dan kodrat perempuan (Mansour, 2013: 9).

Perbedaan gender sesungguhnya tidaklah menjadi masalah sepanjang tidak melahirkan ketidakadilan gender. Namun yang menjadi persoalan, ternyata perbedaan gender telah melahirkan berbagai ketidakadilan, baik bagi kaum laki- laki dan terutama terhadap kaum perempuan. Ketidakadilan gender merupakan sistem dan struktur di mana baik kaum laki-laki maupun perempuan menjadi korban dari sistem tersebut. Untuk memahami bagaimana perbedaan gender melahirkan ketidakadilan gender, dapat dilihat melalui pelbagai manifestasi ketidakadilan yang ada, diantaranya yaitu marginalisasi atau proses pemiskinan ekonomi, subordinasi atau anggapan tidak penting dalam keputusan politik, pembentukan stereotipe atau melalui pelabelan negatif, kekerasan, beban kerja lebih panjang dan lebih banyak, serta sosialisasi ideologi nilai peran gender. Uraian berikut membahas secara lebih rinci masing-masing manifestasi ketidakadilan gender (Mansour, 2013: 12-13).

\section{Gender dan Marginalisasi Perempuan}

Proses marginalisasi yang mengakibatkan kemiskinan sesungguhnya banyak sekali 

DALAM ISLAM (Telaah Pendekatan Kontekstual)"

terjadi dalam masyarakat dan negara yang menimpa kaum laki- laki dan perempuan, misalnya penggusuran, bencana alam atau proses eksploitasi. Namun ada salah satu bentuk pemiskinan atas satu jenis kelamin tertentu, dalam hal ini perempuan yang disebabkan oleh gender. Dari segi sumbernya bisa berasal dari kebijakan pemerintah, keyakinan, tafsiran agama, keyakinan tradisi dan kebiasaan atau bahkan asumsi ilmu pengetahuan. Banyak studi telah dilakukan dalam rangka membahas program pembangunan pemerintah yang menjadi penyebab kemiskinan kaum perempuan. Misalnya, program swasembada pangan atau revolusi hijau (green revolution) Secara ekonomis telah menyingkirkan kaum perempuan dari pekerjaannya sehingga memiskinkan mereka. Di Jawa misalnya, program revolusi hijau dengan memperkenalkan jenis padi unggul yang tumbuh lebih rendah dan pendekatan panen dengan sistem tebang menggunakan sabit, tidak memungkinkan lagi panenan dengan ani-ani, padahal alat tersebut melekat dan digunakan oleh perempuan. Akibatnya banyak kaum perempuan miskin di desa termarginalisasi akhirnya tersingkir karena tidak mendapatkan pekerjaan di sawah pada musim panen. Berarti program revolusi hijau dirancang tanpa mempertimbangkan aspek gender. Marginalisasi juga diperkuat dengan adat istiadat maupun tafsir keagamaan. Misalnya banyak di antara suku-suku di Indonesia yang tidak memberi hak kepada kaum perempuan untuk mendapatkan waris sama sekali. Sebagian tafsir keagamaan memberi hak waris setengah dari hak waris laki-laki terhadap perempuan.

\section{Gender dan Subordinasi}

Pandangan gender ternyata bisa menimbulkan subordinasi terhadap perempuan. Anggapan bahwa perempuan itu emosional sehingga perempuan tidak bisa tampil memimpin, berakibat munculnya sikap yang menempatkan perempuan pada posisi yang tidak penting. Di Jawa, dulu ada anggapan bahwa perempuan tidak perlu sekolah tinggi-tinggi, toh akhirnya akan ke dapur juga. Bahkan, pemerintah pernah memiliki peraturan bahwa jika suami akan pergi belajar (jauh dari keluarga) dia bisa mengambil keputusan sendiri. Sedangkan bagi istri yang hendak tugas belajar ke luar negeri harus seizin suami.

\section{Gender dan Stereotipe}

Banyak sekali ketidakadilan terhadap jenis kelamin tertentu, umumnya perempuan yang bersumber dari penandaan (stereotipe) yang dilekatkan pada mereka. Misalnya, penandaan yang berawal dari asumsi bahwa perempuan bersolek adalah dalam rangka memancing lawan jenisnya, maka setiap ada kasus kekerasan atau pelecehan seksual selalu 

DALAM ISLAM (Telaah Pendekatan Kontekstual)"

dikaitkan dengan stereotipe ini. Masyarakat juga memiliki anggapan bahwa tugas utama kaum perempuan adalah melayani suami. Stereotipe ini berakibat wajar sekali jika pendidikan kaum perempuan dinomorduakan (Mansour, 2013: 13-17).

\section{Gender dan Kekerasan}

Kekerasan adalah serangan atau invasi terhadap fisik maupun integritas mental psikologis seseorang. Banyak macam bentuk kejahatan yang bisa dikategorikan sebagai kekerasan gender, di antaranya: (1) bentuk pemerkosaan terhadap perempuan, (2) tindakan pemukulan dan serangan fisik yang terjadi dalam rumah tangga, (3) penyiksaan yang mengarah kepada organ alat kelamin, misalnya penyunatan terhadap anak perempuan, (4) kekerasan dalam bentuk pelacuran, (5) kekerasan dalam bentuk pornografi, kekerasan dalam bentuk pemaksaan sterilisasi dalam Keluarga Berencana, kekerasan terselubung, yakni memegang bagian tertentu dari tubuh perempuan dengan pelbagai cara dan kesempatan tanpa kerelaan si pemilik tubuh.

\section{Gender dan Beban Kerja}

Adanya anggapan bahwa kaum perempuan memiliki sifat memelihara dan rajin, serta tidak cocok untuk menjadi kepala rumah tangga, berakibat semua pekerjaan domestik rumah tangga menjadi tanggung jawab kaum perempuan. Di kalangan keluarga miskin beban yang sangat berat ini harus ditanggung oleh perempuan sendiri. Terlebih-lebih jika si perempuan tersebut harus bekerja, maka ia memikul beban kerja ganda (Mansour, 2013: 17-21).

Dalam konteks isu gender, perlu kiranya kita mempertajam persoalan dengan menghubungkannnya terhadap prinsip ideal islam dalam memposisikan perempuan. Pertamatama harus dipahami terlebih dahulu apa spirit yang dibawa islam pada awal kelahirannya, yakni melakukan perbandingan atas posisi dan kondisi perempuan pada zaman sebelum dan sesudah islam. Banyak sejarawan mengungkapkan bahwa dalam masyarakat pra-islam atau zaman jahiliyyah, kedudukan perempuan dalam masyarakat sangatlah rendah posisinya dan amat buruk kondisinya, serta dianggap tidak lebih berharga dari suatu komoditas. Dari berbagai uraian tentang penggambaran kedudukan kaum perempuan yang menonjol di antaranya ialah, bahwa jika seorang suami meninggal dunia, saudara tua laki-laki atau saudara laki-laki lainnya mendapat waris untuk memiliki jandanya. Bahkan kebiasaaan mengubur bayi perempuan hidup-hidup adalah praktik merendahkan kaum perempuan yang membentang luas di dunia Arab pada zaman pra-islam. Rendahnya martabat kaum perempuan 

DALAM ISLAM (Telaah Pendekatan Kontekstual)"

juga terlihat dari hakikat perkawinan yang posesif sifatnya. Mereka juga tidak membatasi berapa jumlah perempuan yang boleh dikawini oleh laki-laki.

Al-qur'an sebagai rujukan prinsip masyarakat mengakui bahwa kedudukan laki-laki dan perempuan adalah sama. Keduanya diciptakan dari satu nafs (living entity), di mana yang satu tidak memiliki keunggulan terhadap yang lain. bahkan al-qur'an tidak menjelaskan secara tegas bahwa Hawa diciptakan dari tulang rusuk nabi Adam sehingga kedudukan dan statusnya lebih rendah. Atas dasar itu, prinsip al-qur'an terhadap kaum laki-laki dan perempuan adalah sama, di mana hak istri diakui sederajat dengan hak suami (Mansour, 2013: 128-130). Ada sejumlah nash yang berbicara tentang kemitrasejajaran perempuan dan laki-laki yang dapat dikelompokkan minimal menjadi delapan, yakni: (1) statemen umum tentang kesetaraan wanita dan pria, (2) asal usul, (3) „amal, (4) saling kasih dan mencintai, (5) keadilan dan persamaan, (6) jaminan sosial, (7) saling tolong menolong, (8) kesempatan mendapat pendidikan. Adapun sebab-sebab lahirnya konsep bias gender dalam islam adalah sebagai akibat dari sepuluh faktor, yakni: (1) penggunaan studi islam yang parsial, (2) belum ada kesadaran pentingnya pembedaan nash menjadi normatif-universal dengan praktistemporal, (3) terkesan sejumlah nash memarginalkan wanita sebagai akibat penggunaan parsial, (4) budaya-budaya muslim merasuk terhadap ajaran islam, (5) dominasi teologi lakilaki dalam memahami nash, (6) kajian islam dengan pendekatan agama murni, (7) generalisasi (mengambil hukum umum) dari kasus khusus, (8) mengambil hukum sebagai produk hukum dari penetapan hukum berdasarkan al-siyasah al-syar"iyyah, (9) kajian islam yang literalis dan ahistoris (tekstual), dan (10) peran kekuasaan (penguasa) (Khoiruddin, 2012: 231-232).

Di sisi lain, tafsir keagamaan tetap memegang peran penting dalam melegitimasi dominasi atas kaum perempuan. Persoalannya di sini adalah, mengapa al-qur'an seolah-olah menempatkan kedudukan laki-laki di atas perempuan. Ali Engineer (1992) mengusulkan dalam memahami ayat yang berbunyi "laki-laki adalah pengelola atas perempuan" hendaknya dipahami sebagai deskripsi keadaan struktur dan norma sosial masyarakat pada saat itu, dan bukan suatu norma ajaran. Ayat tersebut menjelaskan bahwa ketika itu laki-laki adalah manager rumah tangga, dan bukan pernyataan kaum laki-laki harus menguasai atau memimpin. Dalam sejarah islam keadaan kaum perempuan berubah, seiring makin berkembangnya kesadaran hak kaum perempuan dan konsep hak juga makin meningkat. Pada 

DALAM ISLAM (Telaah Pendekatan Kontekstual)"

saat ayat tersebut diwahyukan memang belum ada kesadaran tentang hal itu. Kata Qawwam dari masa ke masa dipahami selalu berbeda. Dulu atas dasar ayat itu perempuan dianggap lebih rendah dari laki-laki, dan implikasinya adalah seperti zaman feodal bahwa perempuan harus mengabbdi kepada laki-laki sebagai bagian dari tugasnya. Namun al-qur'an menegaskan bahwa kedudukan suami dan istri adalah sejajar.

Untuk memahami bagaimana kedudukan kaum perempuan, kita dianjurkan untuk memahami konteks surat an-Nisa ${ }^{e e}$ ayat 35 di bawah ini. Diriwayatkan pada suatu hari seorang sahabat Nabi bernama Saad bin Rabi menampar istrinya Habibah bin Zaid karena suatu persoalan. Habibah tidak terima dan mengadukan peristiwa tersebut ke ayahnya. Lantas ayahnya pergi mengadu ke Nabi. Keputusan Nabi adalah meminta Habibah untuk membalasnya. Atas keputusan Nabi tersebut kaum laki-laki di Madinah saat itu protes. Kalau ditarik makna dari peristiwa tersebut, jelas bahwa Nabi telah memperhitungkan dan paham betul akan ada akibatnya, yaitu pasti menghebohkan masyarakat yang didominasi oleh lakilaki. Jadi surat an-Nisae ayat 35 yang menganjurkan untuk mengangkat hakim dalam menyelesaikan perselisihan tersebut diturunkan dengan semangat untuk mengurangi kekerasan terhadap kaum perempuan, dan bukan menegaskan superioritas laki-laki atas perempuan. Namun kenyataannya banyak tafsiran yang tidak mencerminkan dan mengungkapkan kondisi sosial dan kekerasan yang pada saat itu dituntut oleh kaum perempuan agar dihentikan (Mansour, 2013: 132-133). Penulis mengambil kesimpulan bahwa Nabi Muhammad juga mengajarkan adanya kemitrasejajaran antara kaum laki-laki dan perempuan dengan melihat keputusan yang diambil oleh nabi, yaitu meminta Habibah untuk membalasnya.

Bisakah seorang perempuan menjadi kepala negara, pemimpin lembaga atau kepala rumah tangga? Kalau kita telaah melalui al-Qurean, tidak ada alasan yang tegas untuk melarang perempuan menempati posisi seperti itu, kecuali sebuah hadis ahad riwayat Abu Bakar yang menjadi dasar pendukung pandangan ini. Hadis tersebut sangat berlawanan dengan peristiwa Perang Unta di mana Aisyah istri Nabi memimpin Komando Perang, peristiwa yang justru terjadi setelah hadis itu diriwayatkan. Mengapa Abu Bakar sebagai periwayat hadis tersebut tidak memberontak atau desersi atas kepemimpinan Aisyah? Kalau beliau memang percaya bahwa perempuan menurut nabi tidak sah memimpin? Ataukah bahkan nabi sendiri justru tidak membedakan peran laki-laki atau perempuan? Dari petikan 

DALAM ISLAM (Telaah Pendekatan Kontekstual)"

kejadian itu, dapat diambil pernyataan yaitu bahwa tafsir atau interpretasi terhadap ajaran agama sangat dipengaruhi oleh kacamata pandang yang digunakan oleh penafsirnya, yang sering kali juga berkaitan dengan seberapa jauh keuntungan spiritual dan material yang bisa diperoleh, artinya tafsir agama erat kaitannya dengan aspek ekonomi, politik, kultural dan juga ideologi. Dengan demikian diperlukan kajian kritis guna mengakhiri bias dan dominasi dalam penafsiran agama. Maka diperlukan suatu proses kolektif yang mengkombinasikan studi, investigasi, analisis sosial, pendidikan serta aksi untuk membahas isu perempuan. Hal ini termasuk memberikan semangat dan kesempatan perlawanan bagi kaum perempuan guna mengembangkan tafsiran agama yang tidak bias laki-laki. Usaha ini dimaksud untuk menciptakan perimbangan dan perubahan radikal dengan menempatkan perempuan sebagai pusat perubahan. Usaha inilah yang memungkinkan tumbuhnya kesadaran kritis menuju transformasi kaum perempuan (Mansour, 2013: 133-135).

Pemahaman yang bias gender selain meneguhkan subordinasi kaum perempuan, juga mengakibatkan pada persoalan waris dan kesaksian, di mana nilai kaum perempuan dianggap separuh dari laki-laki. Untuk membahas ini perlu dilakukan analisis konteks sosial terhadap struktur sosio-kultural pada saat ayat tersebut diturunkan, sehingga pemahaman masalah waris dan kesaksian tidak bertentangan dengan prinsip keadilan yang telah disampaikan dalam ayat-ayat al-qur'an . Umumnya mereka yang menekuni masalah keadilan gender tidak melihat angka pembagiannya, melainkan semangat keadilannya. Sehingga demi mencapai keadilan, merubah angka yang sesuai dengan sistem dan struktur sosial dewasa ini pun perlu dilakukan (Mansour, 2013: 138).

Mengenai hak waris perempuan dalam konteks sekarang, apakah perempuan selalu harus mendapatkan bagian separuh dari bagian laki-laki? Ini memang tidak salah, tetapi tidak salah juga bagi mereka yang memberikan pembagian harta kepada keluarganya tidak lagi terikat pada teks ayat, tetapi berpegang pada semangat "pengakuan" hak terhadap perempuan untuk mewarisi. Bahkan tidak mustahil, seorang laki-laki diberikan hak separuh dari hak yang diperoleh seorang perempuan, bila ada kesepakatan. Ayat kewarisan ini termasuk kelompok ayat- ayat pendukung (muayyidat), untuk menegakkan keadilan di dalam masyarakat. Sedangkan yang menjadi Maqashid Asy-Syari"ah ayat ini adalah pengakuan hak- hak waris perempuan secara adil dan manusiawi. Porsi satu berbanding dua antara kewarisan dan persaksian anak laki-laki dan anak perempuan di kalangan pemikir islam kontemporer 

DALAM ISLAM (Telaah Pendekatan Kontekstual)"

dipahami sebagai pemberian masa transisi menuju kondisi ideal bagi perempuan dalam memperoleh hak-hak properti.

Ketika dikorelasikan dengan masyarakat Indonesia, pada umumnya penerapan porsi seperti disebutkan dalam masalah di atas, tidak diberlakukan secara umum. Porsi sedemikian ini, biasanya melalui putusan hakim di pengadilan jika alternatif lain tidak disepakati. Hakim di dalam memutuskan persoalan kewarisan, dituntut untuk mempertimbangkan seluruh aspek di dalam lingkungan keluarga yang berperkara, termasuk mempertimbangkan sendi-sendi keadilan yang hidup di dalam masyarakat tempat para pihak yang berperkara itu hidup (Nasaruddin, 2014: 116). Misalnya, ketika dalam sebuah rumah tangga seorang istri menjadi satu-satunya penopang hidup keluarga sementara sang suami dalam keadaan lumpuh atau sakit keras yang mengakibatkan tidak dapat mencari uang. Ditambah lagi problem yaitu anak mereka berjumlah lima, maka ketika istri tersebut mendapat hak waris bersama saudara kandung laki-lakinya yang lain, si istri tersebut boleh mendapatkan hak yang sama dengan saudara laki-lakinya dengan melihat keadaan ekonominya yang mana dia adalah satu-satunya orang yang menopang hidup keluarganya dalam kondisi ekonomi yang sedang kritis. Itulah sebenarnya pesan moral ideal islam dalam konteks sekarang ini.

\section{Solusi Isu Gender dengan Pendekatan Kontekstual}

Misi pokok al-qur'an diturunkan ialah untuk membebaskan manusia dari berbagai bentuk diskriminasi dan penindasan, termasuk diskriminasi seksual, warna kulit, etnis dan ikatan-ikatan primordial lainnya. Oleh karena itu, jika terdapat penafsiran yang menghasilkan bentuk penindasan dan ketidakadilan, maka penafsiran tersebut perlu diteliti kembali. (Nasaruddin, 2014: 13). Pada dasarnya inti ajaran setiap agama, khususnya dalam hal ini islam, adalah menganjurkan dan menegakkan prinsip keadilan, sebagaimana yang terdapat dalam surat al-hujurat ayat 13. Al-qur'an sebagai prinsip-prinsip dasar atau pedoman moral tentang keadilan tersebut, mencakup pelbagai anjuran untuk menegakkan keadilan ekonomi, politik, kultural termasuk keadilan gender. Persoalan muncul ketika masyarakat berkembang dan jenis ketidakadilan juga berkembang seiring dengan perkembangan zaman. Dalam kaitan ini, guna memahami dan menganalisis tentang apa yang adil dan apa yang tidak adil serta bagaimana mekanisme ketidakadilan yang menjadi prinsip agama, maka seseorang membutuhkan pisau analisis ilmu-ilmu sosial dalam hal ini yaitu melihat konteks turunnya ayat al-qur'an terutama melalui pendekatan kontekstual agar prinsip dasar seruan agama 

DALAM ISLAM (Telaah Pendekatan Kontekstual)"

islam untuk menegakkan keadilan tetap relevan. Ada beberapa ayat al-qur'an yang mendukung pandangan bahwa kaum perempuan tidaklah tersubordinasi terhadap kaum lakilaki, seperti dalam surat at-taubah ayat 71, an-nisa' ayat 124, ali imron ayat 195 dan an-nahl ayat 97 (Mansour, 2013: 135-138).

Di sisi lain, kehadiran literatur-literatur islam klasik tentu merupakan kekayaan yang luar biasa dalam dunia islam. Namun literatur-literatur tersebut perlu diposisikan agar umat islam tidak menganggapnya sebagai karya final yang bebas dari kelemahan. Agar nantinya diharapkan dapat sesuai dengan perkembangan zaman dan bisa menjawab permasalahan gender secara proporsional. Kemajuan ilmu, teknologi dan perubahan sosial harus dijadikan sarana dalam membaca ulang literatur klasik islam. Yang harus diperlukan sekarang yaitu membangun sintesa antara Kitab Suci, literatur islam klasik dan sains modern guna mereinterpretasi ulang masalah gender secara mendalam yang mayoritas pemahamannya menyudutkan kaum perempuan (Siti, 2002: 86-87).

Pendekatan kontekstual identik juga dengan metode penafsiran al-qur'an yang disebut dengan metode tafsir $b i$ al-Ra"yi. Tafsir tersebut menjadi sangat urgen untuk dijadikan acuan dalam memahami gender, karena dari studi inilah penafsiran dan pemahaman terhadap ayatayat al-qur'an perlu ditinjau kembali (reinterpretasi) dan reaktualisasi. Dalam dunia keilmuan, tafsir bi al-Ra"yi lebih menekankan pada konteks teks, sehingga penggunaan tafsir ini akan dapat membuka peluang-peluang untuk penafsiran baru yang lebih komprehensif sesuai perkembangan dan kemajuan ilmu pengetahuan di era globalisasi ini serta memungkinkan timbulnya wacana baru yang lebih transparan dalam menjawab isu gender yang lebih logis dan diplomatis (Siti, 2002: 164).

Berdasarkan kacamata kontekstual, di sisi lain transformasi gender bisa memberikan solusi dalam memecahkan isu gender secara proporsional. Transformasi gender merupakan gerakan pembebasan perempuan dan laki-laki dari sistem dan struktur yang tidak adil. Dengan demikian, transformasi gender merupakan upaya pembebasan dari segala bentuk penindasan baik struktural maupun personal, kelas, warna kulit dan ekonomi internasional. Tujuan gerakan transformasi gender tidak sekedar memperbaiki status perempuan yang indikatornya menggunakan norma laki-laki, melainkan memperjuangkan martabat dan kekuatan perempuan. Hal tersebut membutuhkan perubahan peran baik perempuan maupun laki-laki. Dalam hal ini kekuatan bukan berarti mendominasi yang lain. kekuatan yang 

DALAM ISLAM (Telaah Pendekatan Kontekstual)"

dimaksud adalah kekuatan internal dalam rangka mengontrol hidup dan jasad (Mansour, 2013: 66-67). Oleh karena itu, dalam perspektif gender, transformasi sosial sesungguhnya merupakan proses dekonstruksi peran gender dalam seluruh aspek kehidupan di mana terefleksi perbedaan-perbedaan gender yang telah melahirkan ketidakadilan gender.

Dalam ranah lain, tafsiran agama mempunyai kedudukan yang strategis dalam melanggengkan ketidakadilan gender maupun sebaliknya, yaitu dalam usaha menegakkan keadilan gender. Untuk itu diperlukan suatu pengkajian ulang terhadap keseluruhan tafsir agama dan implikasinya terhadap ajaran dan perilaku keagamaan. Kajian tersebut menyangkut identifikasi akar permasalahan dan strategi pemecahannya. Suatu strategi advokasi bisa dipinjam untuk melakukan proses penyadaran dan penafsiran ulang dengan pendekatan sebagai berikut. Jika persoalannya terletak dalam pengertian ayat al-qur'an atau bunyi hadis, maka yang perlu dilakukan adalah penafsiran ulang terhadap ayat-ayat tersebut dengan perspektif gender, penelitian terhadap autentitas hadis tersebut untuk menemukan hadis yang lebih shahih. Hal ini berarti memerlukan usaha yang melibatkan para ulama dan berbagai orang dengan bermacam-macam disiplin ilmu yang mempunyai perspektif gender. Namun jika persoalannya terletak pada penafsirnya, yakni dalam pemahaman para ulama yang memiliki otoritas penafsiran, maka perlu diadakan pendekatan dan pendidikan atau lokakarya guna membahas analisis gender bagi kalangan otoritas ilmu keagamaan tersebut. Namun jika persoalannya terletak pada kultur masyarakat agama yang melanggengkan ketidakadilan gender, yang diperlukan adalah suatu usaha kampanye dan pendidikan massa tentang masalah gender yang dilakukan oleh semua pihak yang peduli terhadap masalah keadilan, termasuk melibatkan para ulama. Untuk itu sudah saatnya lembaga keagamaan dan pendidikan serta lembaga kajian keagamaan memiliki bagian "Pengkajian Perempuan" sebagai wadah yang memberi ruang untuk mengkaji persoalan kedudukan perempuan dalam agama. Dalam masyarakat islam misalnya, perlunya kajian perempuan di pesantren maupun lembaga pendidikan tinggi islam agar nantinya timbul solusi yang aplikatif dalam memecahkan isu gender (Mansour, 2013: 140-141).

\section{Kesimpulan}

Keadilan gender telah menjadi keharusan zaman dalam dunia modern ini. Jika wacana publik masih dipengaruhi oleh pemahaman terhadap teks-teks keagamaan yang tidak 

DALAM ISLAM (Telaah Pendekatan Kontekstual)"

berprespektif gender, maka upaya mewujudkan kesetaraan antara kaum laki-laki dan perempuan sulit direalisasikan. Salah satu cara untuk memecahkan isu gender secara perlahanlahan yaitu melalu pendekatan kontekstual. Pendekatan kontekstual merupakan salah satu pendekatan yang reliable dari beberapa pendekatan dalam rangka memecahkan isu-isu yang beredar dalam studi islam, termasuk di dalamnya yaitu isu gender. Banyak doktrin keagamaan (islam) yang timpang gender karena kebanyakan orang-orang awam memahaminya secara tekstual (apa adanya sesuai teks tersebut) tanpa melihat apa yang ada di balik teks tersebut.

Pada dasarnya inti ajaran agama islam adalah menganjurkan dan menegakkan prinsip keadilan, sebagaimana yang terdapat dalam surat al-hujurat ayat 13. Al-qur'an sebagai prinsipprinsip dasar atau pedoman moral tentang keadilan tersebut, mencakup pelbagai anjuran untuk menegakkan keadilan ekonomi, politik, kultural, sosial termasuk keadilan gender. Persoalan muncul ketika masyarakat berkembang dan jenis ketidakadilan juga berkembang seiring dengan perkembangan zaman. Dalam kaitan ini, guna memahami dan menganalisis tentang apa yang adil dan apa yang tidak adil serta bagaimana mekanisme ketidakadilan yang menjadi prinsip agama, maka seseorang membutuhkan pisau analisis ilmu-ilmu sosial dalam hal ini yaitu melihat konteks turunnya ayat al-qur'an terutama melalui pendekatan kontekstual agar prinsip dasar seruan agama islam untuk menegakkan keadilan tetap relevan sepanjang zaman serta tidak merugikan berbagai pihak baik kaum laki-laki maupun kaum perempuan.

\section{Daftar Pustaka}

Dzuhayatin, Siti Ruhaini, dkk. 2002, Rekonstruksi Metodologis Wacana Kesetaraan Gender dalam Islam, Yogyakarta: Pustaka Pelajar.

Fakih, Mansour. 2013, Analisis Gender dan Transformasi Sosial, Yogyakarta: Pustaka Pelajar. Gramedia. Jakarta: Kencana.

Muhaimin, dkk. 2012, Studi Islam dalam Ragam Dimensi dan Pendekatan,

Nasution, Khoiruddin. 2012, Pengantar Studi Islam, Yogyakarta, ACAdeMia + TAZZAFA.

Syafrudin, 2017. Paradigma Tafsir Tekstual \& Kontekstual Usaha Memaknai Kembali Pesan AlQur"an, Yogyakarta: Pustaka Pelajar.

Umar, Nasaruddin. 2001, Argumen Kesetaraan Gender, Jakarta: Paramadina.

Umar, Nasaruddin. 2014, Ketika Fikih Membela Perempuan, Jakarta: PT Elex Media Komputindo 